\title{
ON THE LINKAGE BETWEEN FDI AND TRADE: EVIDENCE FROM VIETNAM
}

\author{
Supervisor: Anirudh Shingal ${ }^{1}$
}

Authors:

Nguyen Binh Duong ${ }^{2}$, Tu Thuy Anh ${ }^{3}$, Chu Thi Mai Phuong ${ }^{4}$

\begin{abstract}
The purpose of this paper is to examine the linkage between FDI and trade in the case of Vietnam. To investigate this issue, firstly, we attempt to find out the causality relationship between FDI and trade of Vietnam, including exports and imports. Secondly, we try to find out the determinants of Vietnam's bilateral trade by individually applying gravity models for trade, exports and imports. Our main results indicate that there is one way causality linkage between trade and FDI. Concerning the linkage between FDI and import, there is 2 ways causality linkage between these variables: import causes FDI and vice-versa in Granger’s sense.
\end{abstract}

\footnotetext{
* This paper has partly relied on another research work with Dr Tran Thi Anh Dao "Sub-regional Integration Initiatives in East Asia and their implication for Vietnam”, Journal of Social and Policy Sciences, 2010, Vol 1, Number 1, 37-64

${ }^{1}$ Dr Anirudh Ahingal, Senior Research Fellow, Co-leader NCCR-Trade Work Programme, World Trade Institute, Hallerstrasse 6, CH- 3012 Bern

2 Nguyen Binh Duong is PhD of Paris Nord University- France, since 2009 she is lecturer of International Economics at Hanoi Foreign Trade University- Vietnam. Email: nguyenbinhduong@yahoo.com

3 Dr Tu Thuy Anh, Dean of Faculty of International Economics at Hanoi Foreign Trade University-

Vietnam. Email: thuyanh.tu@gmail.com

${ }^{4}$ Chu Thi Mai Phuong is teacher-researcher of International Economics at Hanoi Foreign Trade

University- Vietnam. Email: phuongnamkneu@gmail.com
} 
The empirical result of gravity models shows that Vietnam's bilateral trade flows were positively associated with economic size while the impact of geographical distance appeared to be rather modest. Interestingly, our empirical results show that the effective contribution of Foreign Direct Investment (FDI) inflows may be overestimated. Also, the real exchange rate did not play an important role in promoting Vietnam's exports, while the positive sign associated with its coefficient on the import side is counterintuitive.

More importantly, our empirical results show that Vietnam was constrained by the external balance as its exports and imports reacted differently to the process of trade liberalization within the region. The value of coefficients on the partners' Gross Domestic Output (GDP) suggests that Vietnam was more influenced by external demand shocks than supply shocks: hence, any global crisis will affect more demand for Vietnam's exports than supply of imported commodities. Finally, the intra-regional factor played a significant role in Vietnam's trade expansion. The deepening of subregional integration in East Asia contributed substantially to drive Vietnam's export growth, at the expense of third markets like European Union (EU).

JEL Classification: F14, F15, F21, O11, O19, O53.

Key words: Vietnam, ASEAN+3, East Asia, Regional integration, FDI, Trade, Gravity model. 


\section{INTRODUCTION}

Within the space of three decades, from the country reunification in 1975 to its accession to the World Trade Organization (WTO) in 2007, Vietnam has gone through deep systemic changes. Although the announcement of Doi Moi ("Renovation” in Vietnamese) in 1986 inaugurated the transition experience from centrally planned to market economy, this option was only the political outcome of economic hesitations and confusions emerging from the first reform measures in 1979-81. Vietnam's economic Renovation was then characterized by open, diversified and multilateral foreign policy in the spirit that "Vietnam is ready to be a reliable friend and partner of all nations in the international community, striving for peace, cooperation and development” ("Vietnaman ideal destination for cooperation and investment”, Ministry of planning and investment, 2008). Since then, Vietnam has shown a remarkable performance in terms of economic growth, macroeconomic stabilization and poverty reduction.

The actual performance of Vietnam's external sector is attributable to a sound regime of trade liberalization and strengthened international and regional integration since the early 1990s. In 1992, Vietnam signed a trade agreement with the European Union (EU). In 1995, it joined the Association of Southeast Asian Nations (ASEAN) and committed itself to fulfill the agreements under the ASEAN Free Trade Agreement (AFTA). The country has also been a member of the Asia Pacific Economic Cooperation Forum (APEC) since 1998. Vietnam applied for WTO membership in 1995 and became the $150^{\text {th }}$ WTO member on January 11 , 2007. Previously, it signed a Bilateral Trading Agreement (BTA) with the United States (US) which came into force in December 2001. Since then, Vietnam has also joined several regional integration clubs such as ASEAN-China Free Trade Agreement (ACFTA) in 2002, ASEAN-Japan 
Comprehensive Economic Partnership in 2003, and ASEAN-Korea Free Trade Area in 2006. In the wake of these agreements, the project of an "ASEAN+3" between the ten ASEAN member countries and China, Japan and South Korea, emerged.

In an integrated world economy with many regulating regimes at both multilateral and regional levels, trade and Foreign Direct Investment (FDI) interact in such a way as to be mutually promoting. Although the East Asian financial crisis of 1997-98 interrupted Vietnam's trade expansion, export orientation and integration into the world economy have substantially supported the country's development process. In this perspective, FDI attraction and participation in the international production process might be central to the prospects for Vietnam's long-term growth. It could embark on a development path similar to its East Asian neighbours, which have experienced rapid rise in their share of world trade and income.

One of the key vehicles of economic integration within the region was the ongoing process of internationalization of production through entrance of Transnational Corporations (TNCs) in manufacturing and financial services. Such a strategy aimed at accelerating the industrialization process, has made most East Asian countries strongly interdependent. Due to their participation in complex subcontracting networks, the Asian developing countries are dependent upon the TNCs' organizational structure in order to have the opportunity to benefit from these closer trade-FDI linkages. Exportoriented industrialization strategy may then enhance potential for growth when opportunities for trade based on comparative advantage can increase. But on the contrary, trade and FDI linkages may also provide active transmission channels to external shocks when they occur. This would lead to a situation in which any global 
crisis would be spread and exacerbated both through a traditional multiplier effect bound to the fall of economic activity and domestic demand and, a more prominent matter, through trade inter-linkages along the production networks of vertically linked industries within the area.

In view of these developments, questions then arise on how Vietnam's participation in new sub-regional integration arrangements like ASEAN+3 promote trade, FDI and development. Studies on the impact assessments of Regional Trade Agreements (RTAs) in East Asia must however consider production networking and consequent patterns of trade and FDI across national boundaries. In the specific case of Vietnam, it requires correlating its bilateral trade with the inter-linkages between trade and FDI drawn by its neighbouring partners. This kind of approach would be consistent with the contagion pattern of growth and industrial development among the East Asian countries. Accordingly, our study provides a quantitative assessment on the impact of sub-regional integration on Vietnam's bilateral trade. For the assessment, we use a gravity model to investigate the influence of FDI and trade integration within East Asia on the country's exports and imports. Our panel data analysis is conducted for the period 1992-2006. The paper is organized as follows: Section 2 presents an overview of Vietnam's exportoriented development within the East Asian perspective. Section 3 then presents our empirical analysis. Finally, section 4 concludes and summarizes our main findings. 


\section{VIETNAM'S EXPORT-ORIENTED DEVELOPMENT IN THE EAST ASIAN CONTEXT}

\subsection{Vietnam's economic performance since the Doi Moi}

Vietnam is one of the best performing economies in the world over the past decade. Real GDP has on average grown by 7.5 percent per year during 1990-2004 and the country even reached 8.5 percent in 2007, making it the third consecutive year above the 8 percent benchmark. In terms of current US dollars, per capita income rose from US\$260 in 1995 to a 2007 level of US\$835, while the general poverty rate fell from 58.1 percent in 1993 to 16 percent in $2006^{5}$.

Within a process of both transition and development, the country has embarked in major changes regarding production, investment, distribution and trade in goods and services since the initiation of economic reforms in the mid-1980s. Further reform efforts were devoted to restructuring the State Owned Enterprises (SOEs), the banking and financial system, and tax administration. Also, Vietnam strengthened its international integration by entering discussions about bilateral, regional and multilateral agreements. Several years of intensive negotiations along WTO accession required major changes in laws, regulations and administrative procedures. Parallel to international trade integration, the government pursued the economic reforms and improvements in the investment climate. The first Law on Foreign Investment in Vietnam was dated December 29, 1987 and marked the first step towards renovation of the domestic economy. For the first time, the law established a regime under which FDI could enter Vietnam. Since then, several amendments have been made to the initial Law in order to accommodate foreign investors (Nguyen N.A. and Nguyen T., 2007). In preparation for WTO negotiations, a

\footnotetext{
${ }^{5}$ World Bank: Vietnam - Country Overview, June 2008.
} 
new Unified Enterprise Law was approved on November 29, 2005, followed by a Unified Law on Investment ${ }^{6}$ that came into force on July 1, 2006. These amendments cancel all previous laws and regulations that discriminated foreign firms in relation to domestic firms and aim to treat them equally according to the WTO principle of national treatment (which states that foreigners must benefit from the same treatment as one's own nationals). Most importantly, they insist upon the attraction of FDI as a key strategy to promote growth and exports in the country.

\section{$<$ Insert Figure 1 >}

Vietnam has experienced a dramatic increase in FDI inflows since the mid-1990s, attesting to the successful implementation of trade and investment reforms (Figure 1). Consistent with other countries in the region, FDI inflows decreased sharply during the East Asian crisis of 1997-98, but they rebounded quickly in 2001 and have grown uninterruptedly since then. As a result, Vietnam has overtaken the Philippines and Indonesia to become the third largest recipient of FDI inflows in the ASEAN and is increasingly viewed as an alternative destination to countries such as China or Thailand (Nguyen N.A. and Nguyen T., 2007). Due to its advantageous location in a rapid growing region, it has become an attractive location for efficiency-seeking FDI through its participation to subcontracting networks and international division of labour. The surge in FDI inflows by 2007 attests to foreign investors' expectations in an overall business climate with Vietnam's accession to the $\mathrm{WTO}^{7}$. What is striking, however, is that FDI inflows in Vietnam show a greater magnitude than in the other countries of East Asia: in 2006, inward FDI reached 11.5 percent of fixed capital formation and 54.8

\footnotetext{
${ }^{6}$ Several other laws, including the Competition Law or the Bankruptcy Law, were approved by the National Assembly and contributed to clarify the status of private enterprises in Vietnam.

${ }^{7}$ According to the World Bank (East Asia Pacific Update, April 2008), FDI commitments almost doubled, to 20.3 billion US\$.
} 
percent GDP in Vietnam, compared to respectively 10.7 percent and 26.8 percent for the East Asian area as a whole. The similar measures were only 8.2 percent and 11.1 percent for China.

\section{$<$ Insert Table 1>}

Table 1 depicts the distribution of FDI by top investors in Vietnam. In contrast to the early years of implementation of the Foreign Investment Law, East Asia is now the most important source of foreign capital in the country. As predicted, Japan and the first-tier Newly Industrialized Economies (NIEs) are the top five of foreign investors (also trans-shipping through the British Virgin Islands) and account for 67 percent of total investment. This predominance of regional investors greatly explains the sharp drop of FDI inflows in Vietnam following the onset of the East Asian crisis. Unsurprisingly, the main investor outside East Asia is the United States after the embargo was lifted in 1994 and the coming into effect of the US-Vietnam Bilateral Trade Agreement (US-VN BTA) in 2001. France and the European Union as a whole lag far behind the Asian investors with only about 10 percent of the number of projects and 15 percent of total investment.

The Foreign Investment Law allows foreign investors to enter Vietnam in one of three forms: enterprises with 100 percent foreign ownership, Joint-Ventures (JVs) and Contractual Business Cooperation. In the early years of the Foreign Investment Law, JVs were the most common form of investment, with a peak in 1995-96. Some changes have occurred in recent years, due to Vietnam's continuous efforts in improving the investment environment. In particular, numerous incentives have been applied to promote export-oriented investments: simplification of administrative procedures, building centralized industrial zones, export processing zones with favourable physical 
infrastructures and preferential conditions. In 1991, wholly-owned affiliates accounted for about 20 percent of total invested capital and 10 percent of the number of projects; by 2000, these proportions had risen to 90 percent and 83 percent respectively. Moreover, they mainly originated from East Asian enterprises in search of cost reduction and regional location complementation in manufacturing activities.

Since the implementation of the Foreign Investment Law, the foreign-invested sector has gained rapid and stable development. Its share in total industrial production has increased considerably: from 4.5 percent in 1990 to 43.8 percent in 2007, the highest proportion being registered in the whole industrial sector. In terms of industrial growth, the foreign invested sector always witnessed a better performance: for the period 19962000, it reached 22.4 percent per year in comparison with 13.9 percent for the overall industrial growth rate. From 2001 to 2007, the rates were 17.4 percent and 16.3 percent per year respectively.

Among the crucial factors contributing to Vietnam's remarkable performance is the export sector, which grew at an annual growth rate of 16 percent during the last ten years and above the 20 percent benchmark since 2003. By the end of 2007, total exports reached 68 percent of GDP, bringing international reserves to 30.2 percent of GDP or 3.3 months worth of imports ${ }^{8}$. The impressive performance of the export sector is ascribable to a great deal of continuing effort to improve trade policies (Tran 2010). Vietnam's law on export-import tariffs was first launched on January 1, 1988 along with the Foreign Investment Law promulgated in 1987. The trade reform process was strongly supported between 1989 and the early years of the 1990s; it then suffered a

\footnotetext{
${ }^{8}$ World Bank: Vietnam - Country Overview, June 2008.
} 
standstill during the mid-1990s, but was resumed after 1998. Over the past fifteen years or more, non-tariff import restrictions which created trade distortions have been abolished gradually, while favourable incentives have been applied to exports. Since then, exports have become the main driver of growth.

During the period 1993 to 2004, Vietnam's trade openness (exports + imports as a percent of GDP) rose from 54.2 percent to 123.9 percent, while the market share of its exports (exports of goods as a percent of world imports of goods) more than trebled, from 0.08 percent to 0.29 percent (Tumbarello 2006). It is an impressive record of performance compared with other countries in the East Asian region: China, in particular, was less open to trade (26.9 percent in 1993 and 68.2 percent in 2004) and 'only' doubled its export market share (from 5.74 percent to 9.64 percent during the same period). By 2007, the trade openness ratio reached 156 percent and was strongly debated among the officials; however, some of them argue that this high dependence on foreign trade is attributed to the industrialization process, as most of the inputs used in the production for export are imported. The structure of exports and imports evidences this argument.

\section{$<$ Insert Table 2>}

In accordance with the export-led growth strategy, there is a sign of improvement in Vietnam's export structure with an apparent increase of manufactured products at the expense of primary products. Exports of manufactured products reached 52 percent by 1997: in comparison, the 50 percent threshold was reached by China in 1986, by the Philippines in 1984, by Thailand and Malaysia in 1989 and by Indonesia in 1995 (Chaponnière, Cling and Zhou, 2009). However, when we have a deeper look at the export structure (Table 2), we find that the ten major commodities accounted for almost 
three-quarters of export revenues in 2006: namely, crude oil (20.7 percent of total exports $^{9}$ ), garments and footwear, seafood, furniture, electronic appliances and the key primary products (coffee, rice, etc.).

On the other hand, Vietnam's main imports are machine tools, electrical equipment, steel and chemical products to meet the country's demand for modern technology and materials as the industrial development proceeds (Table 2). Imports surged by almost 40 percent in 2007, with growth especially strong for capital goods (56.5 percent). Growth was also strong for intermediate goods (40 percent) used in the production of garments and footwear, chemical products, plastic and livestock. This dependence on imports for industrial production explains an unusually large deficit of the current account in 2007, in the range of 9.3 to 9.7 percent of $\mathrm{GDP}^{10}$. It was also attributed to increases in international prices and the impact of local tariff reductions in accordance with the WTO commitments. This trade pattern indicates that Vietnam may face balance of payments problems and the role of export performance is then emphasized because no other component of aggregate demand provides the foreign exchange to pay for import requirements associated with the expansion of output.

\subsection{Vietnam and regional integration in East Asia}

There has been current proliferation of bilateral and preferential trading arrangements in East Asia. Consistent with its ongoing participation in the world economy however, Sakakibara and Yamakawa (2003) observed that East Asia’s trade and FDI patterns are global and, at the same time, intra-regional ${ }^{11}$. Due to the highly multilateral nature of its

\footnotetext{
${ }^{9}$ Crude oil will go down in the next few years as Vietnam has built oil refineries in the country.

${ }^{10}$ World Bank: Vietnam - Country Overview, June 2008.

11 This has been denominated "open regionalism”.
} 
trade and FDI, East Asia still maintains the importance of extra-regional relationships. But at the same time, intra-regional relationships are strengthening as individual countries attempt to grow in the shadow of China which is becoming the primary production centre of the region. Consequently, there are several types of regional and sub-regional arrangements designed to promote intra-Asian trade and FDI. For instance, the establishment of AFTA in Singapore Summit by January 1992 aimed at an obvious liberalisation and deep integration within ASEAN. But more recently, the ACFTA is indicative, rather, of a cooperative approach preferable to adopting a defensive, protectionist stance against the challenge of China.

A further approach to regionalism consists in surpassing preferential agreements and viewing trade and FDI linkages within East Asia through the cross-border activities of TNCs. These firms have created efficiency production networks and supply chains within the region. But their establishment is broader in concept than regional trade and FDI agreements. For the East Asian countries, it is one step in moving towards a full membership of the global production network. In short, the regional network should operate within and as a part of the international production network. Illustrative of this approach, clothing, electronics and automobiles are the three industrial sectors that have figured in international production networks involving developing countries.

Concomitant reforms of trade and investment regimes in the Asian developing countries, together with industrial restructuring of the more advanced countries, have brought the Flying Geese Paradigm (FGP) pioneered by Akamatsu (1962) up to date. This metaphor has been used to describe the shift of industries from one country to another in East Asia, with the inverted V-shaped curves representing the evolution of the same industry in different countries overtime, in relation to the dynamics of comparative advantage. It 
provides a description of the life-cycle of various industries in the course of economic development, but involves also a regional division of labour based on an industrial and location hierarchy. In this process, trade and FDI are the main mechanisms by which development is transmitted from one country to another. They contribute both to transfer new industrial goods, to recycle comparative advantages and to relocate those sectors suffering from loss of competitiveness. Furthermore, the FGP has induced a conceptual framework for linking regional integration to the major interconnected changes in the international trade structure within East Asia (Memis and Montes 2006). In aggregate, intra-regional trade development can be assessed by trade indices. The Trade Intensity Index $\left(\mathrm{TII}_{\mathrm{ij}}\right)$ is first used to determine whether the value of trade between two countries is greater or smaller than would be expected on the basis of their importance in world trade. It is defined as the share of country $i$ 's trade going to partner $j$ divided by the share of world trade going to the same partner. It is calculated as:

$$
\operatorname{TII}_{\mathrm{ij}}=\frac{\mathrm{t}_{\mathrm{ij}} / \mathrm{T}_{\mathrm{iw}}}{\mathrm{t}_{\mathrm{wj}} / \mathrm{T}_{\mathrm{ww}}}
$$

where:

$t_{\mathrm{ij}}$ and $\mathrm{t}_{\mathrm{wj}}$ are the values of total trade of country $i$ and of world trade with country $j$ $\mathrm{T}_{\mathrm{iw}}$ and $\mathrm{T}_{\mathrm{ww}}$ are the total trade of country $i$ with the world and the total world trade An index of more (less) than one indicates that bilateral trade flow between countries $i$ and $j$ is larger (smaller) than expected given their importance in world trade.

Intra-regional trade calculations can be based on the ratio of intra-regional trade share to the share of world trade with the region, using only exports data. The Intra-regional Trade Intensity Index $\left(\mathrm{ITII}_{\mathrm{i}}\right)$ is then computed as: 


$$
\text { ITII }_{i}=\frac{X_{\mathrm{ii}} /\left(\left(\mathrm{X}_{\mathrm{iw}}+\mathrm{X}_{\mathrm{wi}}\right) / 2\right)}{\left(\left(\mathrm{X}_{\mathrm{iw}}+\mathrm{X}_{\mathrm{wi}}\right) / 2\right) / \mathrm{X}_{\mathrm{ww}}}
$$

where: $\mathrm{X}_{\mathrm{ii}}$ is exports of region $i$ to region $i, \mathrm{X}_{\mathrm{ww}}$ is total world exports

$\mathrm{X}_{\mathrm{iw}}$ is exports of region $i$ to the world, $\mathrm{X}_{\mathrm{wi}}$ is exports of world to region $i$

The numerator defines the intra-regional trade share as a percentage of the total trade of the region, while the denominator measures the region's importance in world trade. An index greater than one indicates that trade flow within the region is larger than expected given the importance of the region in world trade. The opposite holds when the index is smaller than one.

\section{$<$ Insert Figure 2>}

Figure 2 reports on the right-hand side axis, the evolution of the Trade Intensity Index $\left(\mathrm{TII}_{\mathrm{ij}}\right)$ for Vietnam either in destination to the world or to sub-regional markets (ASEAN, ASEAN+3, East Asia $15^{12}$ ): by comparison, we have calculated the same indices for the whole ASEAN. On the left-hand axis, the graph displays, through histograms, changes over time in the Intra-regional Trade Intensity Index (ITII $\mathrm{i}_{\mathrm{i}}$ for the three sub-regional groupings. It can be seen that all indices far exceed one during the period 1991-2008, indicating that the East Asian countries have become important trade partners for individual countries in the region, including Vietnam. Indeed, the latter trades more with its neighbours (notably ASEAN member countries) than would be expected given their importance in world trade. Similarly, the Intra-regional Trade Intensity Indices are very high irrespective of the sub-regional groupings. Two factors explain this development: first, the rapid economic growth of some emerging countries in the region,

\footnotetext{
${ }^{12}$ ASEAN+3 consists of the 10 ASEAN member countries; China, South Korea and Japan. East Asia 15 enlarges ASEAN+3 by adding Hong Kong and Taiwan.
} 
which has demand linkages on the neighbours; second, the ongoing wave of productionsharing schemes, boosted by the trade liberalization measures implemented under various preferential trading arrangements during the 1990s. In particular, the economic reform and trade liberalisation policy attributed to China's WTO membership, as well as the diversified outward-oriented policy aimed to increase their export market shares, have been the engine of trade growth among countries within the region. China has been overtaking Japan as the major trading partner in the region, owing to the intra-Asian trade focus on the former.

When we have a deeper look at the trade statistics however, it can be seen that Vietnam's exports and imports have changed differently over time. While only its import share from ASEAN+3 has increased uninterruptedly since 2003 (above the 60 percent benchmark since 2004), its export shares to the three sub-regional groupings have declined consecutively since 2005. By 2008, Vietnam's export shares to ASEAN+3 and East Asia 15 were 37.3 percent and 40.7 percent respectively, after a peak of 60.8 percent in 1993 for the former and 73.9 percent in 1991 for the latter. This opposite tendency explains the slight decline of the TII for Vietnam in the last years and may be attributed to export market diversification with WTO accession.

In November 2004, the ASEAN+3 leaders agreed to establish an East Asian Community to be the long-term objectives and affirmation for future enlarged ASEAN integration. As it is expected to enhance growth and improve trade and investment linkages more effectively in East and South East Asia, the agreement content should be "WTO plus common characteristics". 
However, the ASEAN enlargement issue is currently debated in terms of benefits and costs for the ASEAN members, notably the least developed ones. Firstly, the new trading arrangements imply further economic liberalization in a broad range of goods, services and investment; however, despite the high economic complementarities between the ASEAN+3 partners, the sensitive sectors are of great concerns. Secondly, the ASEAN enlargement aims to expand the market access for trade and investment. However, the framework was initially proposed and mainly driven by China and followed by Japan: it is not sure that the latecomers like Vietnam may benefit from the regional market access but be crowded out. The participation of very heterogeneous economies questions on how the gains from trade integration will be distributed among the country members. Thirdly, it is well known that the bilateral trade of most individual countries are closely related with export markets outside the region, especially the USA and EU. Consequently, the expanding trade share and volume of intra ASEAN+3 largely depend on how China could play the role of engine of growth for the whole area. According to the United Nations Conference on Trade and Development (UNCTAD, 2008), the latter has been the locomotive of export expansion from developing countries in general and of trade among themselves in particular. The benefits from sub-regional arrangements then largely depend on how the country participates in the triangular (South-South-North) trading networks within the region and to which extent it trades with China. The issue is addressed here by focusing on Vietnam's case study and applying gravity model estimations on its bilateral trade. 


\section{CAUSALITY LINKAGE BETWEEN FDI AND TRADE: THE CASE OF VIETNAM}

Firstly, we use the Granger causality methodology to test for the relationship between FDI and each variable: trade, exports, and imports. .

In a bivariate framework, the variable $\mathrm{x}$ is said to cause the variable $\mathrm{y}$ in the Granger sense if the forecast for $\mathrm{y}$ improves when lagged variables for $\mathrm{x}$ are taken into account in the equation, (Penélope Pacheco-López, 2005). In other words, the standard Granger causality procedure is based on past changes in one variable explaining actual changes in another variable.

Testing causality, in the Granger sense, involves using an F-test (or Wald test). The appropriate formulation of a Granger-type test of causality (which must be applied to stationary series) is:

$$
\begin{aligned}
& F D I_{t}=\alpha_{0}+\alpha_{1} F D I_{t-1}+\ldots+\alpha_{j} F D I_{t-j}+\gamma_{1} T_{R A D E_{t-1}}+\ldots .+\gamma_{j} T_{R A D E_{t-j}}+v_{t} \\
& T R A D E_{t}=\delta_{0}+\delta_{1} T_{R A D E_{t-1}}+\ldots+\delta_{j} T_{R A D E_{t-j}}+\phi_{1} F D I_{t-1}+\ldots .+\phi_{j} F D I_{t-j}+\mu_{t} \\
& E X_{t}=\theta_{0}+\theta_{1} E X_{t-1}+\ldots+\theta_{j} E X_{t-j}+\tau_{1} F D I_{t-1}+\ldots .+\tau_{j} F D I_{t-j}+\varphi_{t} \\
& F D I_{t}=\eta_{0}+\eta_{1} F D I_{t-1}+\ldots .+\eta_{j} F D I_{t-j}+\rho_{1} E X_{t-1}+\ldots+\rho_{j} E X_{t-j}+\vartheta_{t} \\
& F D I_{t}=\xi_{0}+\xi_{1} F D I_{t-1}+\ldots+\xi_{j} F D I_{t-j}+\psi_{1} I M_{t-1}+\ldots .+\psi_{j} I M_{t-j}+\kappa_{t} \\
& I M_{t}=\lambda_{0}+\lambda_{1} I M_{t-1}+\ldots .+\lambda_{j} I M_{t-j}+\beta_{1} F D I_{t-1}+\ldots+\beta_{j} F D I_{t-j}+\sigma_{t} \\
& j=1,2, \ldots \ldots . ., N
\end{aligned}
$$

where EX is exports, FDI is foreign direct investment, IM is imports; $v_{t}, \mu_{t}, \varphi_{t}, \vartheta_{t}, \kappa_{t}, \sigma_{t}$ are error terms with zero mean.

In equation (1), the null hypothesis "EX does not Granger-cause FDI" $\left(\gamma_{1}=\ldots .=\gamma_{j}=0\right)$ is tested using a standard F-test (Wald test). It is rejected if the ${ }^{\gamma}$ 's are jointly significantly different from zero. Similarly, in equation (2) the null hypothesis "FDI does not Granger-cause EX" $\left(\phi_{1}=\ldots=\phi_{j}=0\right)$ is rejected if the $\phi$,s 
are jointly significantly different from zero. The same procedure applies for equations (3), (4), (5) and (6).

Considering the ARDL model, an error-correction model for each of the six equations is derived:

$$
\Delta y_{t}=\lambda_{0}+\sum_{i=1}^{r} \beta_{y i} \Delta y_{t-i}+\sum_{i=0}^{s} \beta_{x i} \Delta x_{t-i}+\pi \rho_{t-1}+\varepsilon_{t}
$$

Where $\rho_{t-1}$ is the lagged error-correction term obtained from the residuals in each equation (equations (1) to (6) and $\varepsilon_{t}$ is the random disturbance term. From equation (7) the null hypothesis that "x does not Granger-cause y" would be rejected if the lagged coefficients of the $\beta_{x i}$, s are jointly significantly different from zero, using a standard F-test (Wald test). In case of cointegration between $\mathrm{x}$ and $\mathrm{y}$, changes in one variable towards its long-run equilibrium value may be a result of variations in the other variable. As well, the causality between $\mathrm{x}$ and $\mathrm{y}$ could be identified if the error term $\left(\rho_{t-1}\right)$ is statistically significant. Notice that the Granger test results only indicate that the changes in $\mathrm{x}$ must come before the changes in $\mathrm{y}$. A statistically significant coefficient on $\rho_{t-1}(\pi)$ shows how the short run coefficients of the endogenous variable adjust towards the long-run equilibrium in reaction to changes in the exogenous variables.

\section{<Insert Annex 1, 2 and 3>}

The empirical result shows that there is one way causality linkage between trade and FDI: Trade causes FDI, but FDI does not cause Trade in Granger's sense. Concerning FDI and export, there is not causality relationship between these two variables. And on the linkage between FDI and import, there is 2 ways causality linkage between these variables: import causes FDI and vice-versa in Granger's sense ( Annex 1, 2 and 3). 


\section{A GRAVITY MODEL FOR ASSESSING THE IMPACT OF FDI ON TRADE IN THE CASE OF VIETNAM}

\subsection{Model specification and data}

Gravity models have become predominant in the last four decades in empirical analysis of bilateral trade and foreign investment because of its convenience and high degree of flexibility. The basic underpinning of gravity models is Newton's Law of Gravitation which states that two celestial bodies are subjected to a force of attraction that is directly proportional to their mass and indirectly proportional to their distance. The application of gravity equations to empirical analysis of international trade was pioneered by Tinbergen (1962). According to the early gravity equations, the amount of trade between two countries is explained by their economic size and geographical distance:

$$
F_{i j}={ }^{A} Y_{i} Y_{j} / D_{i j}
$$

where:

$F_{\mathrm{ij}}$ is the trade flow (i.e. migration, trade, capital) from country $i$ to country $j$ at time $t$ A is a constant of proportionality

$\mathrm{Y}_{\mathrm{i}}$ and $\mathrm{Y}_{\mathrm{j}}$ is a proxy of the country size (GDP or population)

$\mathrm{D}_{\mathrm{ij}}$ is the geographical distance between countries' capitals or economic centres

The estimations employ a log-linear form of the above equation: the expected signs of the coefficients state that bilateral flow between country $i$ and country $j$ is positively associated with size $\left(Y_{i}\right.$ and $\left.Y_{j}\right)$ and inversely related to distance $\left(D_{i j}\right)$, the latter being a proxy for transaction costs. The underlying assumption is that a high level of income indicates a high level of production which would lead to a high level of exports in the 
exporting country. In a similar way, a high level of GDP in the importing country also implies a high level of imports from the partner. Also, one may expect that larger countries trade less in relative terms and consequently the impact of population should be negative. On the other hand, trade is restrained by longer distance as it makes trade costlier.

Several modifications have contributed to the improvement of the early gravity equations by adding new variables such as the level of economic development (per capita GDP), the share of rural population, cultural similarities, linguistic characteristics, political stability and institutions et cetera. In the specific case of preferential trading arrangements, Aitken (1973) was the first to apply cross-section gravity models to assess the impact of RTA membership on bilateral trade flows. Since then, a huge number of empirical studies used gravity models to explore the effects of regional groupings: Memis and Montes (2006) present some of them in Asia and the Pacific.

Despite extensive literature using this approach, the empirical studies based on gravity model estimation are still rather limited in the case of Vietnam. In a recent study, Nguyen and Xing (2008) applied the gravity model to analyze Vietnam's exports; however, any single-country approach needs to estimate both exports and imports as the trade flows are asymmetric. Nguyen (2002) attempted to address the effects of AFTA on Vietnam by examining both exports and imports: but his cross-section regression was only estimated for the years 1995, 1996, 1997 and 1998. Also, Chaisrisawatsuk S. and Chaisrisawatsuk W. (2007) used the gravity model to explain simultaneously the imports, exports and total trade of 29 Organization for Economic Co-operation and Development (OECD) countries and 6 ASEAN member countries. But their study did 
not mention Vietnam. By contrast, Tumbarello (2006) investigated the extent to which Vietnam's favourable trade performance may have been excessively centred on trade with other countries in the region: however, the study was applied to cross-country data for only one year (that is 2002) and regressed for the total trade.

In consequence, our paper overcomes these limitations by separately estimating exports and imports in a panel dataset. The use of individual gravity models has the advantage of observing whether exports and imports reacted differently to the process of trade liberalization. Moreover, the main reason for preferring panel data analysis is that the cross-section specification is very likely to suffer from omitted variable bias because of the unobserved country specific effects. Cross-section specification has also the disadvantage to completely neglect the temporal aspects of foreign trade. Therefore adopting panel regression techniques allow us to take advantage of these different types of information.

Let us estimate separately models for Vietnam: one for the trade , one for exports and one for the imports. All empirical studies assume a log-linear functional form for gravity equations. The 3 models are defined and then estimated as follows:

$$
\begin{aligned}
& \ln T R A D E_{j, t}=\alpha_{0}+\alpha_{1} \ln G D P_{v, t-1}+\alpha_{2} \ln G D P_{j, t}+\alpha_{3} \ln D I S T_{v j}+\alpha_{4} \ln F D I_{j, t}+\alpha_{5} R E_{j, t}+\alpha_{6} A S I A+\alpha_{7} C O L O N Y+\mu_{j}+\varepsilon_{j, t} \\
& \ln E X_{j, t}=\alpha_{0}+\alpha_{1} \ln G D P_{v, t-1}+\alpha_{2} \ln G D P_{j, t}+\alpha_{3} \ln D I S T_{v j}+\alpha_{4} \ln F D I_{j, t}+\alpha_{5} R E_{j, t}+\alpha_{6} A S I A+\alpha_{7} C O L O N Y+\mu_{j}+\varepsilon_{j, t} \\
& \ln I M_{j, t}=\beta_{0}+\beta_{1} \ln G D P_{v, t-1}+\beta_{2} \ln G D P_{j, t}+\beta_{3} \ln D I S T_{v j}+\beta_{4} \ln F D I_{j, t}+\beta_{5} R E_{j, t}+\beta_{6} A S I A+\alpha_{7} C O L O N Y+\mu_{j}+\varepsilon_{j, t}
\end{aligned}
$$


Refer to Granger test result before; it is interesting to estimate the impact of import to FDI. The last model is defined and the estimated as follows:

$\ln F D I_{j, t}=\beta_{0}+\beta_{1} \ln I M_{v, t}+\beta_{2} \ln G D P_{v, t-1}+\beta_{3} \ln G D P_{j, t}+\beta_{4} \ln D I S T_{v j}+\beta_{5} R E_{j, t}+\beta_{6} A S I A+\beta_{7} C O L O N Y+\mu_{j}+\varepsilon_{j, t}$

where:

$\mathrm{EX}_{\mathrm{j}, \mathrm{t}}$ is Vietnam's exports to country $j$ at time $\mathrm{t}$

$\mathrm{IM}_{\mathrm{j}, \mathrm{t}}$ is Vietnam's imports from country $j$ at time $\mathrm{t}$

$\mathrm{GDP}_{\mathrm{v}, \mathrm{t}-1}$ and $\mathrm{GDP}_{\mathrm{j}, \mathrm{t}}$ are the gross domestic product of Vietnam and country $j$ respectively at time (t-1) and $\mathrm{t}$

$\mathrm{DIST}_{\mathrm{vj}}$ is the bilateral distance between Vietnam and country $j$, which is time-invariant $\mathrm{FDI}_{\mathrm{j}, \mathrm{t}}$ is bilateral FDI from country $j$ to Vietnam at time $\mathrm{t}$

$R E_{j, t}$ is real bilateral exchange rate between Vietnam and country $j$ (foreign currency in terms of Vietnamese currency) at time $t$

ASIA is a dummy variable which takes the value 1 if the trading partner $j$ belongs to the sub-regional trading arrangement ASEAN+3 and 0 otherwise

COLONY is a dummy variable which takes the value 1 if Vietnam was colony of the trading partner $j$ and 0 otherwise

$\mu_{j}$ captures all individual (country specific) effects omitted from our model specification

$\varepsilon_{j, t}$ is a normally distributed error term

Trade, export and import data are obtained at dollar values from United Nations Statistics Division (UNSTAT) and converted into real terms. FDI data is based on annual registered stock of FDI published by the Vietnamese General Statistics Office. 
We focus here on the eleven major investors ${ }^{13}$ in Vietnam from 1992 to 2006. In 2006, these main foreign investors accounted for 71.8 percent of Vietnam's imports and 61 percent of exports. FDI data for the years 1991 to 1995 are referred to Nguyen and Xing (2008). The nominal GDP of both Vietnam and its trading partners are collected from UNCTAD database source and converted into real terms. However, to avoid the problem of endogeneity between domestic income and external trade, we use one period lagged variable for Vietnam’s GDP in our gravity models. Comparative costs of trading are captured here by bilateral real exchange rates, which are calculated as the product of the nominal exchange rate and relative price levels in each country. They are collected from the United States Department of Agriculture's data set, and are computed on a 2005 base. Geographical distances are obtained online from the notre-planete.info website (included in references).

\subsection{Empirical results}

The ordinary least squares (OLS) method is firstly used to estimate the coefficients of the explanatory variables. As shown in Tables 3, 4, 5.1 and 5.2, the $\mathrm{R}^{2}$ indicates that approximately 78 percent, 66 percent, 75 percent and 78 percent of the variability in the total trade, exports, imports and FDI between Vietnam and the partner countries can be explained by the model. However, the resulted estimators may be biased or inconsistent in the presence of specific effects: in consequence, we check robustness of our regressions and examine the sensitivity of our results to alternative estimation methods. We choose to estimate the gravity models in a panel data framework with random

\footnotetext{
${ }^{13}$ China, France, Hong Kong, Japan, Malaysia, Netherlands, Singapore, South Korea, Taiwan, Thailand, USA.
} 
effects after having proceeded to the Hausman test and validated our specification by concluding to the presence of inter-individual correlation between the model residuals and the independent variables for each country (Breusch-Pagan LM test). Also, we test for the presence of heteroscedasticity and autocorrelation on error terms. The empirical results show that autocorrelation between errors is absent (no intra-individual autocorrelation), but there is heteroscedasticity on error terms of both models: this may arise due to misspecification of the equation or variation in the coefficients. By the modified Wald test, we can identify the form of heteroscedasticity: that is intraindividual homoscedasticity and inter-individual heteroscedasticity. It indicates that the countries in our sample have different propensities to trade with Vietnam. The Generalized Least Squares (GLS) method with random effects is then performed to correct for inter-individual heteroscedasticity and correlation (Tables 3, 4, 5.1 and 5.2, ).

\section{$<$ Insert Table 3> \\ <Insert Table 4> \\ $<$ Insert Table 5.1 > \\ <Insert Table 5.2>}

As expected, the coefficient associated with the Vietnamese GDP is statistically significant in 4 models at the 99 percent confidence level and of positive sign, indicating that an increase in national income leads to an increase in Vietnam's external trade and inward FDI of Vietnam. In trade model, the coefficient explains that an increase of 1\% GDP leads to an increase of 2, 86\% of Vietnamese trade. Vietnam's export oriented strategy is then partly explained by supply capacity: a high level of 
national income indicates a high level of production, which increases the availability of goods for exports. Our results confirm that, like most of the Asian developing countries, Vietnam experienced a dramatic increase in export growth and this outstanding performance was mainly driven by domestic supply capacity growth (Diaw, Rieber and Tran, 2009). But although larger than one, the coefficient in the export model is lower than the one in the import model (1.37 and 1.96 respectively): this may suggest that Vietnam's economic structure tends to be more dependent on imports, despite the option for an export oriented strategy. Rather, the latter may explain ceteris paribus an increase in the income elasticity of imports and the resulting constraint on balance of payments.

Vietnam's bilateral trade is also positively influenced by its trading partners' GDP: the coefficient is statistically significant and equal to 1.16 ; 0.77 ; and 0.37 respectively in variability in the total trade, exports, and imports models. That means a 1 percent increase in the trading partners' income will boost 1.16 percent in trade; 0.77 percent in export and 0.37 percent in imports. A value of elasticity less than one indicates that Vietnam's bilateral trade grows proportionally less than foreign income. However, the country is slightly more influenced by external demand shocks than supply shocks: notably, any global crisis will affect more foreign demand for Vietnam's exports through the traditional multiplier effect than foreign supply of capital goods or intermediated inputs for domestic production. In FDI model, the statistically insignificant shows that FDI in Vietnam is not influenced by GDP of trading partners. As expected, the coefficient on distance is statistically significant and has the expected sign in trade, export and import models. However, the very low value in 4 models suggests that geographical proximity does not explain Vietnam's bilateral trade as much 
as predicted. It implies that other kinds of trade barriers may determine transaction costs in the specific case of Vietnam.

One may expect that an increase of real exchange rates will promote exports but reduce imports. The coefficient on the bilateral real exchange rate is statistically significant in both models and of positive signs: a depreciation of the Vietnamese Dong promoted exports but inversely did not decrease imports. The latter result is counter-intuitive but consistent with the fact that Vietnam needs to import machinery and equipment, steel and chemical products to meet the country's demand for key commodities and materials as the industrial development proceeds. Because the local industry cannot meet the domestic demand for production yet, the country has to fill the gap by importing. Nevertheless, the very low coefficients suggest that the real exchange rate played a minor role in Vietnam's bilateral trade with the countries under study. This fact is reconfirmed by statistically insignificant coefficient in FDI model.

The coefficient on ASIA highly significant in our gravity models and has a positive sign. With a value greater than one in the export model, the sub-regional integration contributed to Vietnam's exports through foreign market access and a demand-led expansion within East Asia. More importantly, the sub-region seemed to play an even greater role in supplying Vietnam, as the coefficient of the regional dummy is equal to 3.26 on the import side and 1.98 on the FDI model. This result evidences a trade reorientation towards the Asian neighbours at the expense of third markets like EU. Looking at the second dummy variable, the coefficient on Colony is significant in import model. Nevertheless, the very low coefficients suggest that the colony played a minor role in Vietnam's bilateral trade with the countries under study. This fact is reconfirmed by coefficient statistically insignificant in trade, export and FDI model. 
Finally, in complement to the traditional gravity variables, an overall positive relation between Vietnam's foreign trade and FDI is expected as the two variables interact in such a way as to be mutually promoting. In the conventional gravity models, export supply capacity of a country is primarily determined by its GDP whereas the export demand is determined by GDP of the importing countries. However, if a country has a large stock of export-oriented FDI, its export supply capacity will be higher than the country with the same level of GDP but less stock of export-oriented FDI. Furthermore, if the foreign investors are mainly motivated by supplying the home country market, FDI will raise exports from the host country in destination to the FDI source country. Hence, the higher the level of FDI, the more Vietnam bilaterally trades with the FDI source country. The seminal result may be reinforced if the trading partner lies within East Asia.

According to our estimates, the coefficients on FDI are equal to $0.23 ; 0.08$ and 0.12 in the trade, export and import models respectively. In particular, Vietnam seems to import relatively more from the partners which invest within the country. However, the low coefficient values mean that FDI has not explained the country's bilateral trade as much as predicted: specifically, a 1 percent increase in FDI will only increase Vietnam's exports by 0.08 percent while explaining 0.12 percent growth in its imports, and 0.23 percent growth in total trade. This is not surprising as most of the early FDI inflows were attracted by State-owned enterprises in key import-substituting industries (Tran 2010). Another explanation derives from Vietnam's current export pattern: Vietnam is specialized in labour-intensive and resource-based exports and this induces intersectoral or "horizontal" trade. By contrast, the ongoing production-sharing schemes among the forecomers in East and Southeast Asia draw closer trade-FDI connections 
and consequent "vertical” trade (Chaponnière et al. 2009). In FDI model, the coefficient of import is statistically insignificant, this fact shows that import don't influence on FDI of Vietnam. All in all, our results suggest that the effective contribution of FDI inflows to Vietnam's export performance may be overestimated in the literature.

\section{CONCLUSION}

Trade and FDI have given a specific dimension to the rapidly growing East Asian countries by contributing to the acceleration of industrial growth and structural change along their development process. Following their footsteps, the actual performance of Vietnam's external sector has been attributable to a sound regime of trade liberalization and strengthened international integration since the early 1990s. In this context, our paper aimed to assess the impact on Vietnam's trade of FDI which has been proposed in recent years. There is a development in trading arrangements within East Asia which are expected to promote trade, FDI inflows and economic growth among the members. However, the ASEAN enlargement to ACFTA, then ASEAN+3 is currently debated: notably because the regional integration may progress differently among the member countries and this will not necessarily result in effective growth. In the specific case of Vietnam, this requires correlating its bilateral trade with the inter-linkages between trade and FDI drawn by its neighbouring partners.

For this purpose, causality Granger test were used to determine the linkage between trade, export, import and FDI. The empirical result shows that there is one way causality linkage between trade and FDI. Concerning FDI and export, there is not causality relationship between these two variables. And on the linkage between FDI and import, there is 2 ways causality linkage between these variables: import causes FDI and viceversa in Granger’s sense. 
Secondly, gravity models were estimated separately for trade, exports and imports to explore the determinants of bilateral trade between Vietnam and its main country partners since the early 1990s. Interestingly, our empirical results show that exports and imports reacted differently to the process of trade liberalization. In particular, Vietnam's bilateral trade flows were differently associated with its economic size: although larger than one, the coefficient associated with the Vietnamese GDP in the export model is lower than the one in the import model. This may suggest that Vietnam's economic structure tends to be more dependent on imports, despite the option for an export oriented strategy. A higher income elasticity of demand for imports and a lower income elasticity of demand for exports reveal that Vietnam was constrained by balance of payments restrictions. Thus, in terms of prospects for further economic development, our results suggest that there is room for export diversification in order to elevate the income elasticity of demand for exports and relax the balance of payments constraint. By the same token, the value of coefficients on the main partners' GDP implies that Vietnam was more influenced by external demand shocks than supply shocks: hence, any global crisis will affect more foreign demand for Vietnam's exports than domestic imports of capital goods or intermediated inputs for production. The impact of geographical distance (which is a proxy of transaction costs) is negative but appeared to be rather modest. It implies that other kinds of trade barriers may determine transaction costs in the specific case of Vietnam.

In complement to the traditional gravity variables, our results suggest that the effective contribution of FDI inflows to Vietnam's external trade may be overestimated in the literature. In relative terms however, FDI attraction encourages more imports than exports and, combined to trade liberalization, there is the fear that Vietnam will face 
tighter balance of payments constraints. The real exchange rate did not play an important role in promoting Vietnam's exports, while the positive sign associated with its coefficient on the import side is counter-intuitive. In fact, the country was constrained to import most of its export related production commodities, even though the real exchange rate development made them more expensive.

Finally, the intra-regional factor played a significant role in Vietnam's trade expansion. In terms of foreign outlets, the fast growth of some emerging countries in East and Southeast Asia (notably China) was an engine of export growth for Vietnam at the expense of third markets like the EU. But at the same time, they tended to play a greater role in supplying Vietnam. As the largest wave of production-sharing schemes has been found in the dynamic East and South-East Asia, the ongoing implication of Vietnam in such regional trading networks for manufacturing parts and components will enhance this joint but divergent trend in exports and imports. 


\section{References}

Aitken, N.D. (1973): "The effect of the EEC and EFTA on European trade: A temporal cross-section analysis”, American Economic Review, 63, 881-892.

Akamatsu, K. (1962): “A historical pattern of economic growth in developing countries”, The Developing Economies 1, 3-25.

Binh Duong Nguyen, Tran Thi Anh-Dao (2010): "Sub-regional Intergration Initiatives in East Asia and their implication for Vietnam”, Journal of Social and Policy Sciences, Vol 1, Number 1, 37-64

Chaisrisawatsuk, S. and W. Chaisrisawatsuk (2007): "Imports, exports and foreign direct investment interactions and their effects", in ESCAP, Towards coherent policy frameworks: understanding trade and investment linkages - A study by the AsiaPacific Research and Training Network on Trade, United Nations, New York, 97115.

Chaponnière, J.R., J.P. Cling and B. Zhou (2009), "Vietnam following China's footsteps: The third wave of emerging Asian economies", in Santos-Paulino A.U. and Wan G. (eds.), Southern Engines of Global Growth and the role of FDI, New York, Oxford University Press.

Diaw D., A. Rieber and T.A.D. Tran (2009): "On the role of Foreign Market Access in SouthSouth trade: Application to Sub-Saharan Africa and the Developing Asia”. Presented at the international conference "Vietnam and East Asian countries facing the world crisis", Foreign Trade University (15 December 2009, Hanoi, Vietnam).

Memis E. and M.F. Montes (2006): "Assessing RTAs in the Context of the Flying Geese Framework”, Occasional Paper Series O-2006-18, United Nations University, Comparative Regional Integration Studies (UNU-CRIS), August.

Nguyen, T.T. (2002): "Vietnam's Trade liberalisation in the context of ASEAN and FTA”, CAS Discussion Paper $n^{\circ} 36$, Centre for ASEAN Studies, January.

Nguyen, N.A. and T. Nguyen (2007): "Foreign Direct Investment in Vietnam: An Overview and Analysis the Determinants of Spatial Distribution across Provinces", MPRA Paper $n^{\circ} 1921$, Munich Personal Repec Archive, November. 
Nguyen, T.X and Y. Xing (2008): "Foreign direct investment and export the experiences of Vietnam”, Economics of Transition, 16(2), 183-197.

Notre-planete.info website:

http://www.notre-planete.info/geographie/outils/distances.php

Sakakibara, E. and S. Yamakawa (2003): "Regional integration in East Asia. Challenges and opportunities”, Policy Research Working Paper 3079, World Bank, Washington D.C., June.

Tinbergen, J. (1962): Shaping the world economy, New York, Twentieth Century Fund.

Tran, T.A.D. (2010): “Vietnam's export performance in the face of China's competitive challenge”, Comparative Economic Studies, 52(2), 2010, p. 1-23, forthcoming.

Tumbarello, P. (2006): Does Vietnam overtrade with its neighbouring countries? A regional investigation using a gravity model, IMF Selected Issues.

UNCTAD (2008): Development and globalization: Facts and Figures 2008, United Nations, New-York and Geneva. 
Figures and Tables

Figure 1: FDI in Vietnam, 1990-2007

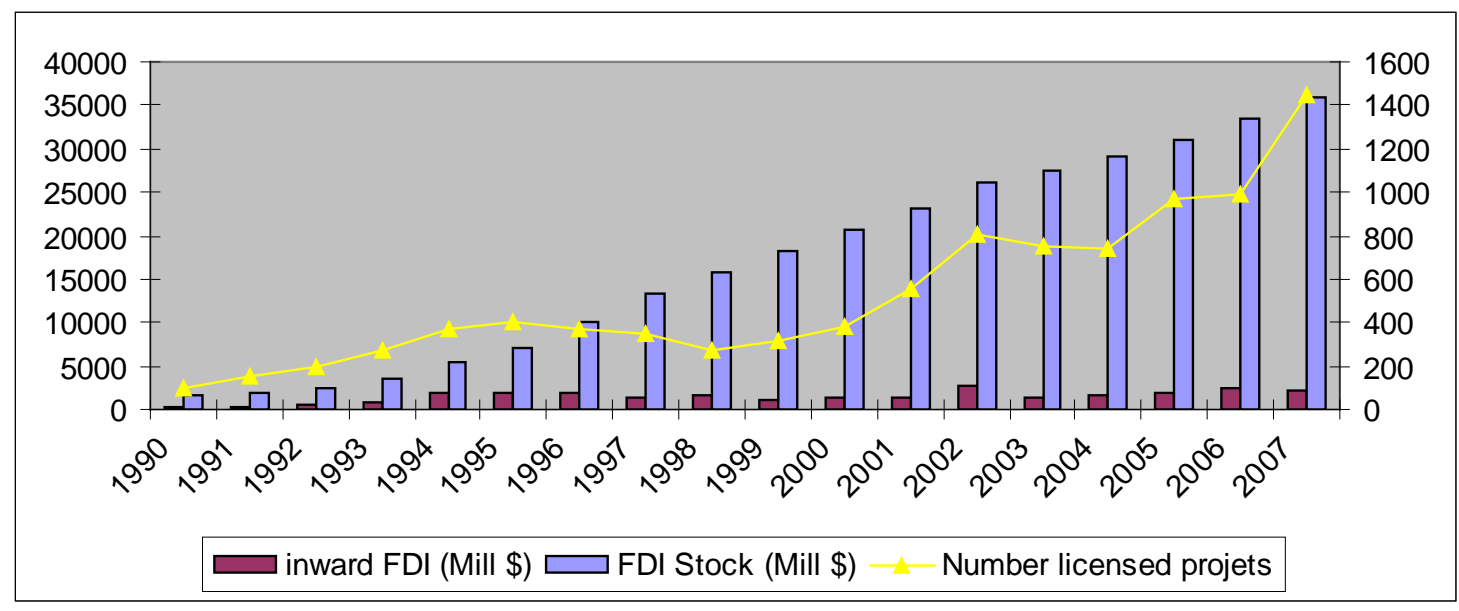

Source: Vietnamese Ministry of Planning and Investment (MPI)

Figure 2: Vietnam's external trade development

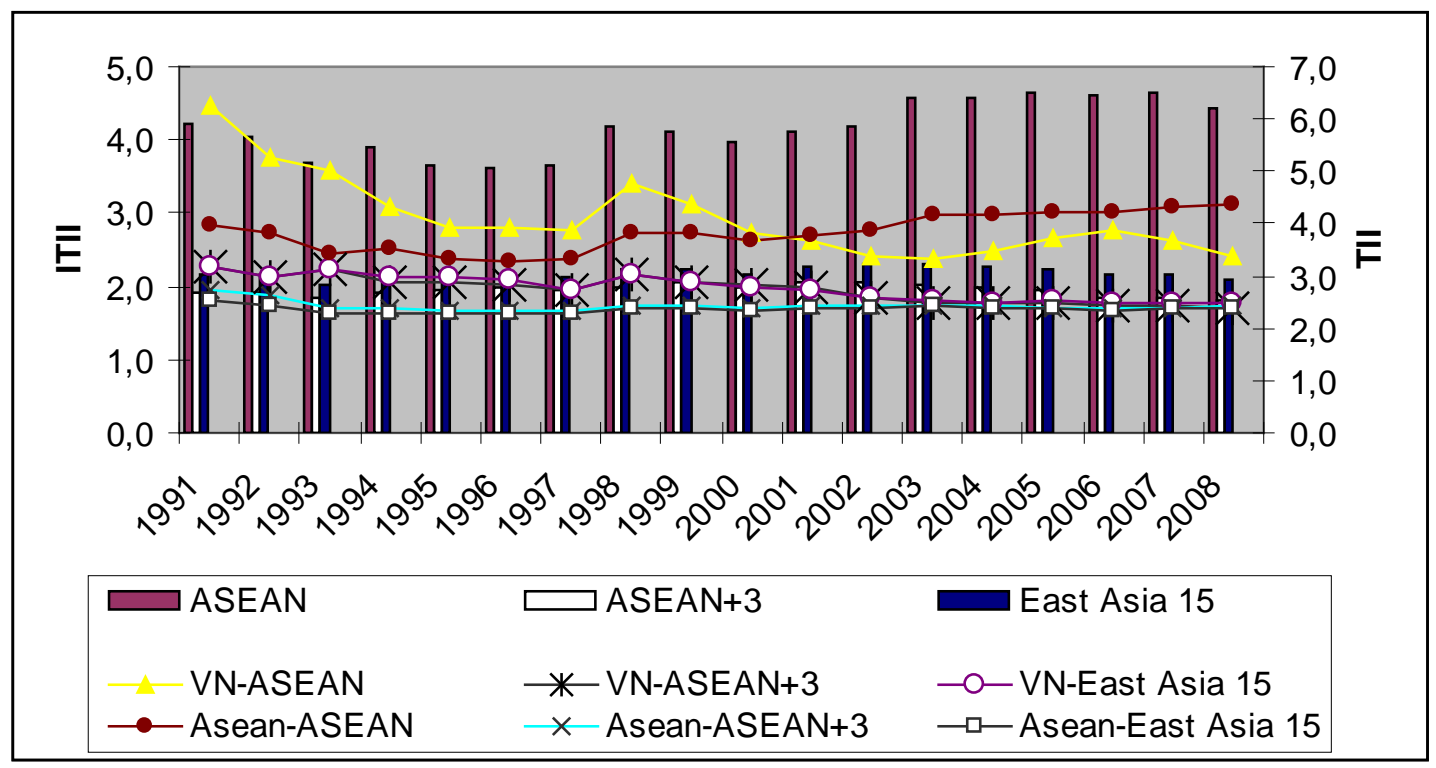

Source: IMF Trade Statistics 
Table 1: Top ten FDI Countries updated to 31 December 2007 (in millions USD)

\begin{tabular}{clcccc}
\hline Rank & \multicolumn{1}{c}{ Country } & $\begin{array}{c}\text { Number of } \\
\text { projects }\end{array}$ & $\begin{array}{c}\text { Capital } \\
\text { investment }\end{array}$ & $\begin{array}{c}\text { Registered } \\
\text { capital }\end{array}$ & $\begin{array}{c}\text { Executed } \\
\text { capital }\end{array}$ \\
\hline 1 & South Korea & 1857 & 14398 & 5168 & 2738 \\
2 & Singapore & 549 & 11059 & 3894 & 3858 \\
3 & Taiwan & 1801 & 10763 & 4599 & 3079 \\
4 & Japan & 934 & 9180 & 3963 & 4987 \\
5 & BritishVirginIslands & 342 & 7795 & 2612 & 1376 \\
6 & Hong Kong & 457 & 5933 & 2167 & 2161 \\
7 & Malaysia & 245 & 2823 & 1797 & 1083 \\
8 & The USA & 376 & 2789 & 1450 & 746 \\
9 & Netherlands & 86 & 2599 & 1482 & 2031 \\
10 & France & 196 & 2376 & 1441 & 1085 \\
\hline
\end{tabular}

Table 2: Vietnam's main exports and imports by commodity in 2006

\begin{tabular}{|c|c|c|c|c|}
\hline Rank & Exports & $\begin{array}{c}\% \text { of total } \\
\text { exports }\end{array}$ & Imports & $\begin{array}{l}\text { \% of total } \\
\text { imports }\end{array}$ \\
\hline 1 & Crude oil & 20.7 & Machinery and equipment & 14.8 \\
\hline 2 & Textiles and garments & 14.6 & Petroleum products & 13.3 \\
\hline 3 & Footwear & 9 & $\begin{array}{l}\text { Steel and irons } \\
\text { Electronic and computer }\end{array}$ & 6.5 \\
\hline 4 & Marine products & 8.4 & components & 4.6 \\
\hline 5 & Wood products & 4.8 & Chemicals and chemical products & 4.6 \\
\hline 6 & Electronic and computer parts & 4.3 & Material for garment and footwear & 4.3 \\
\hline 7 & Tea and coffee & 3.3 & Plastic materials & 4.1 \\
\hline 8 & Rice & 3.2 & Wood, sawn and log & 1.7 \\
\hline 9 & Rubber & 3.2 & Animal feed and materials & 1.6 \\
\hline \multirow[t]{2}{*}{10} & Coal & 2.3 & Fertilizers & 1.5 \\
\hline & Sub-total & 73.8 & Sub-total & 57 \\
\hline
\end{tabular}

Source: World Bank 
Table 3: Results of estimation on Trade

\begin{tabular}{|c|c|c|}
\hline \multirow[t]{2}{*}{ Independent variables } & \multicolumn{2}{|c|}{ Dependent variable $\ln \left(\mathrm{TRADE}_{\mathrm{j}, \mathrm{t}}\right)$} \\
\hline & OLS estimation & $\begin{array}{c}\text { GLS (with } \\
\text { random effects) }\end{array}$ \\
\hline Constant & $\begin{array}{c}-67.21 \\
(-11.23)^{* * *} \\
\end{array}$ & $\begin{array}{c}-68.19 \\
(-38.64)^{* * *} \\
\end{array}$ \\
\hline $\ln \left(\mathrm{GDP}_{\mathrm{v}, \mathrm{t}-1}\right)$ & $\begin{array}{c}2.90 \\
(15.95)^{* * *}\end{array}$ & $\begin{array}{c}2.86 \\
(45.26)^{* * *}\end{array}$ \\
\hline $\ln \left(\mathrm{GDP}_{\mathrm{j}, \mathrm{t}}\right)$ & $\begin{array}{c}1.12 \\
(3.82)^{* * *}\end{array}$ & $\begin{array}{c}1.16 \\
(25.79)^{* * *}\end{array}$ \\
\hline $\ln \left(\mathrm{FDI}_{\mathrm{j}, \mathrm{t}}\right)$ & $\begin{array}{c}0.21 \\
(2.73)^{* * *} \\
\end{array}$ & $\begin{array}{c}0.23 \\
(15.01)^{* * *}\end{array}$ \\
\hline $\mathrm{RE}_{\mathrm{j}, \mathrm{t}}$ & $\begin{array}{c}0.00028 \\
(4.17)^{* * *} \\
\end{array}$ & $\begin{array}{c}0.00030 \\
(21.15)^{* * *}\end{array}$ \\
\hline $\operatorname{DIST}_{\mathrm{vj}}$ & $\begin{array}{c}-0.00037 \\
(-1.19) \\
\end{array}$ & $\begin{array}{c}-0.00040 \\
(-6.85)^{* * *}\end{array}$ \\
\hline ASIA & $\begin{array}{c}4.96 \\
(1.99)^{* *}\end{array}$ & $\begin{array}{c}5.16 \\
(14.08)^{* * *} \\
\end{array}$ \\
\hline COLONY & $\begin{array}{c}-0,07 \\
(-0,13) \\
\end{array}$ & $\begin{array}{c}-0.09 \\
(-1.12) \\
\end{array}$ \\
\hline $\mathrm{R}^{2}$ & 0.78 & \\
\hline Number of observations & 165 & \\
\hline
\end{tabular}

Note: $* * *$ and $* * *$ denote significance at the $10 \%, 5 \%$ and $1 \%$ levels respectively. The numbers in brackets are z-statistics 
Table 4: Results of estimation on Exports

\begin{tabular}{|c|c|c|}
\hline Independent variables & \multicolumn{2}{|c|}{ Dependent variable $\ln \left(\mathrm{EX}_{\mathrm{j}, \mathrm{t}}\right)$} \\
\hline & OLS estimation & $\begin{array}{c}\text { GLS (with } \\
\text { random effects) }\end{array}$ \\
\hline Constant & $\begin{array}{c}-35.84 \\
(-10.10)^{* * *}\end{array}$ & $\begin{array}{c}-36.53 \\
(-39.77)^{* * *}\end{array}$ \\
\hline $\ln \left(\mathrm{GDP}_{\mathrm{v}, \mathrm{t}-\mathrm{t}}\right)$ & $\begin{array}{c}1.38 \\
(11.5)^{* * *}\end{array}$ & $\begin{array}{c}1.37 \\
(50.86)^{* * *}\end{array}$ \\
\hline $\ln \left(\mathrm{GDP}_{\mathrm{j}, \mathrm{t}}\right)$ & 0.74 & 0.77 \\
$(5.19)^{* * *}$ & $(25.12)^{* * *}$ \\
\hline $\ln \left(\mathrm{FDI}_{\mathrm{j}, \mathrm{t}}\right)$ & 0.08 & 0.08 \\
& $(1.65)^{*}$ & $(11.86)^{* * *}$ \\
\hline \multirow{2}{*}{$\mathrm{RE}_{\mathrm{j}, \mathrm{t}}$} & 0.00017 & 0.00018 \\
\hline \multirow{2}{*}{$\mathrm{DIST}_{\mathrm{vj}}$} & $(4.87)^{* * *}$ & $(21.02)^{* * *}$ \\
\hline \multirow{2}{*}{$\mathrm{ASIA}$} & -0.00030 & -0.00032 \\
& $(-2.17)^{* *}$ & $(-8.19)^{* * *}$ \\
\hline COLONY & 1.72 & 1.79 \\
& $(1.61)^{*}$ & $(7.53)^{* * *}$ \\
\hline $\mathrm{R}^{2}$ & -0.25 & -0.25 \\
$(-0.99)$ & \\
\hline Number of observations & \multicolumn{2}{|c|}{$165)^{* * *}$} \\
\hline
\end{tabular}

Note: $*, * *$ and $* * *$ denote significance at the $10 \%, 5 \%$ and $1 \%$ levels respectively. The numbers in brackets are z-statistics 
Table 5.1: Result of estimation on Import

\begin{tabular}{|c|c|c|}
\hline Independent variables & \multicolumn{2}{|c|}{ Dependent variable $\ln \left(\mathrm{IM}_{\mathrm{j}, \mathrm{t}}\right)$} \\
\hline & OLS estimation & $\begin{array}{c}\mathrm{GLS} \text { (with } \\
\text { random effects) }\end{array}$ \\
\hline Constant & $\begin{array}{c}-41.97 \\
(-11.31)^{* * *}\end{array}$ & $\begin{array}{c}-42.60 \\
(-32.12)^{* * *}\end{array}$ \\
\hline $\ln \left(\mathrm{GDP}_{\mathrm{v}, \mathrm{t}-1}\right)$ & $\begin{array}{c}1.89 \\
(17.74)^{* * *}\end{array}$ & $\begin{array}{c}1.96 \\
(32.57)^{* * *}\end{array}$ \\
\hline $\ln \left(\mathrm{GDP}_{\mathrm{j}, \mathrm{t}}\right)$ & 0.57 & 0.37 \\
& $(2.82)^{* * *}$ & $(16.60)^{* * *}$ \\
\hline $\ln \left(\mathrm{FDI}_{\mathrm{j}, \mathrm{t}}\right)$ & 0.02 & 0.12 \\
\hline $\mathrm{RE}_{\mathrm{j}, \mathrm{t}}$ & $(0.60)$ & $(13.36)^{* * *}$ \\
\hline DIST & 0.00008 & 0.00012 \\
$\mathrm{vj}$ & $(1.83)^{*}$ & $(14.08)^{* * *}$ \\
\hline ASIA & -0.00027 & -0.000073 \\
& $(-1.08)$ & $(-3.02)^{* * *}$ \\
\hline COLONY & 1.41 & 3.26 \\
& $(0.66)$ & $(20.34)^{* * *}$ \\
\hline $\mathrm{R}^{2}$ & -0.49 & 0.17 \\
\hline Number of observations & $(-0.09)$ & $(3.30)^{* * *}$ \\
\hline
\end{tabular}

Note: $* * *$ and $* * *$ denote significance at the $10 \%, 5 \%$ and $1 \%$ levels respectively. The numbers in brackets are z-statistics 
Table 5.2: Result of estimation on FDI

\begin{tabular}{|c|c|c|}
\hline Independent variables & \multicolumn{2}{|c|}{ Dependent variable $\ln \left(\mathrm{FDI}_{\mathrm{j}, \mathrm{t}}\right)$} \\
\hline & OLS estimation & $\begin{array}{c}\text { GLS (with } \\
\text { random effects) }\end{array}$ \\
\hline \multirow{2}{*}{ Constant } & 1.76 & 15.75 \\
& $(0.98)$ & $(3.52)^{* * *}$ \\
\hline \multirow{2}{*}{$\ln \left(\mathrm{GDP}_{\mathrm{v}, \mathrm{t}-1}\right)$} & 1.15 & 0.38 \\
& $(0.98)$ & $-0.72)^{* * *}$ \\
\hline \multirow{2}{*}{$\ln \left(\mathrm{GDP}_{\mathrm{j}, \mathrm{t}}\right)$} & -1.19 & $(-1.04)$ \\
\hline \multirow{2}{*}{$\ln \left(\mathrm{IM}_{\mathrm{j}, \mathrm{t}}\right)$} & $(-0.53)$ & -0.07 \\
& 0.82 & $(-0.68)$ \\
\hline \multirow{2}{*}{$\mathrm{RE}_{\mathrm{j}, \mathrm{t}}$} & $(2.37)^{* *}$ & -0.00002 \\
& 0.000018 & $(-0.74)$ \\
\hline \multirow{2}{*}{ DIST } & $(0.24)$ & 0.00024 \\
& -0.00052 & $(2.15)^{* *}$ \\
\hline \multirow{2}{*}{ ASIA } & $(-1.34)$ & 1.98 \\
& -2.07 & $(2.14)^{* *}$ \\
\hline COLONY & $(-0.65)$ & 0.006 \\
& -0.85 & $(0.03)$ \\
\hline $\mathrm{R}^{2}$ & $(-1.11)$ & \\
\hline Number of observations & 0.78 & \\
\hline
\end{tabular}




\section{ANNEX:}

\section{Causality relationship between TRADE - FDI}

\section{VAR Granger Causality/Block Exogeneity Wald Tests}

Sample: 19922006

Included observations: 154

Dependent variable: TRADE

\begin{tabular}{llll}
\hline \hline Excluded & Chi-sq & df & Prob. \\
\hline \hline FDI & 2.344352 & 1 & 0.1257 \\
\hline \hline All & 2.344352 & 1 & 0.1257 \\
\hline \hline
\end{tabular}

Dependent variable: FDI

\begin{tabular}{llll}
\hline \hline Excluded & Chi-sq & df & Prob. \\
\hline \hline TRADE & 4.926256 & 1 & 0.0265 \\
\hline \hline All & 4.926256 & 1 & 0.0265 \\
\hline \hline
\end{tabular}

[At 5\% significance level]

- Trade $\rightarrow$ FDI in Granger's sense

- $\quad$ FDI does not $\rightarrow$ Trade in Granger's sense

\section{Causality relationship between EXPORT - FDI}

VAR Granger Causality/Block Exogeneity Wald Tests

Sample: 19922006

Included observations: 143

Dependent variable: EXPORT

\begin{tabular}{llll}
\hline \hline Excluded & Chi-sq & df & Prob. \\
\hline \hline FDI & 0.992703 & 2 & 0.6087 \\
\hline \hline All & 0.992703 & 2 & 0.6087 \\
\hline \hline
\end{tabular}


Dependent variable: FDI

\begin{tabular}{llll}
\hline \hline Excluded & Chi-sq & df & Prob. \\
\hline \hline EXPORT & 2.831507 & 2 & 0.2427 \\
\hline \hline All & 2.831507 & 2 & 0.2427 \\
\hline \hline
\end{tabular}

- Export does not $\rightarrow$ FDI in Granger's sense

- FDI does not $\rightarrow$ Export in Granger's sense

\section{Causality relationship between IMPORT - FDI}

VAR Granger Causality/Block Exogeneity Wald Tests

Sample: 19922006

Included observations: 154

Dependent variable: IMPORT

\begin{tabular}{llll}
\hline \hline Excluded & Chi-sq & df & Prob. \\
\hline \hline FDI & 9.739440 & 1 & 0.0018 \\
\hline \hline All & 9.739440 & 1 & 0.0018 \\
\hline \hline
\end{tabular}

Dependent variable: FDI

\begin{tabular}{llll}
\hline \hline Excluded & Chi-sq & df & Prob. \\
\hline \hline IMPORT & 4.614808 & 1 & 0.0317 \\
\hline \hline All & 4.614808 & 1 & 0.0317 \\
\hline \hline
\end{tabular}

- Import $\rightarrow$ FDI in Granger’s sense

- FDI $\rightarrow$ Import in Granger's sense 